\title{
The geothermal potential of Jizan area, Southwestern parts of Saudi Arabia
}

\author{
Aref Lashin ${ }^{1,2 *}$ and Nassir Al Arifi ${ }^{1}$ \\ ${ }^{1}$ Geology and Geophysics Department, College of Science, King Saud University, P. O. Box 2455, Riyadh 11451, \\ Saudi Arabia. \\ ${ }^{2}$ Geology Department, Faculty of Science, Benha University, P.O. Box 13518, Benha, Egypt.
}

Accepted 16 November, 2011

\begin{abstract}
The geothermal resources of Saudi Arabia are mainly located in the southwestern parts associated with a series of volcanic rocks and ridges. Jizan area is considered as one of the most promising geothermal targets which are characterized by the presence of a number of structural related hot springs with a surface temperature range of 46 to $79^{\circ} \mathrm{C}$ at the surface. This work mainly aims to throw light on the possible potentiality of these resources at Jizan area, through analyzing the available satellite images and interpreting the geothermometer data. A number of Landsat and Spot satellite images, which cover the study area, are analyzed. The drainage pattern, digital elevation model and the prevailing structural elements are all interpreted. Three main thermal anomalies are recognized (Al Ardah, Al Khouba and Bani Malik), and more closely located to the east, away from the coastal plain in areas of high and complicated topographic nature, and originating from hard crystalline rocks. The general slope decreases notably westward from $45^{\circ}$ in the high hill areas to $1^{\circ}$ near the sea coast. The prevailing drainage patterns are mainly denderitic, running seaward and associated with up to four seaward-oriented coastal basins. A geo-thermometer based study (Silica, $\mathrm{Na}, \mathrm{K}$ and $\mathrm{Mg}$ ) was performed by analyzing the different water samples collected from the different studied hot springs and adjacent water wells to determine the subsurface formation temperature, heat flow and water type. Much higher thermal regimes are recognized in the localities occupied by the hot springs as compared with other surrounding areas. Maximum values up to $152^{\circ} \mathrm{C}$ and $210 \mathrm{~mW} / \mathrm{M}^{2}$ are recorded for the subsurface temperature and heat flow respectively. The studied hot springs are promised and needs to be further investigated and accessed by additional geophysical methodologies.
\end{abstract}

Key words: Hot springs, geothermal, land sat, geothermometers, Saudi Arabia.

\section{INTRODUCTION}

Kingdom Saudi Arabia occupies a very advanced rank all over the world in terms of the huge proven oil and gas reserves which it attains and the very low actual production cost per barrel. Although, no actual energy problem seem to appear in the near future of the kingdom, there was a strategic tendency in the last few years to substitute the hydrocarbon-related energy resources (oil and natural gas) with other renewable source of energy to free up additional crude oil for export.

${ }^{*}$ Corresponding author. E-mail: aref70@hotmail.com. Tel: +966540852336 .
Renewable energy has several unique characteristics that should be considered when making comparisons to oil-based alternatives (Ahmed, 1994; Alnatheer, 2007). Geothermal resources either in the form of subsurface thermal collectives (hot dry rock) and/or surface hydrothermal hot springs are considered among the most important sources of renewable energy which is not actually studied in Saudi Arabia. Majority of these geothermal resources are concentrated in the southwestern parts, in the form of a number of hot springs and surface hot pools. The upcoming thermal water reaches the surface through a complex grid of structural elements which in general, follow the main tectonic elements and activities prevailing in the whole Red Sea area. In so doing, 


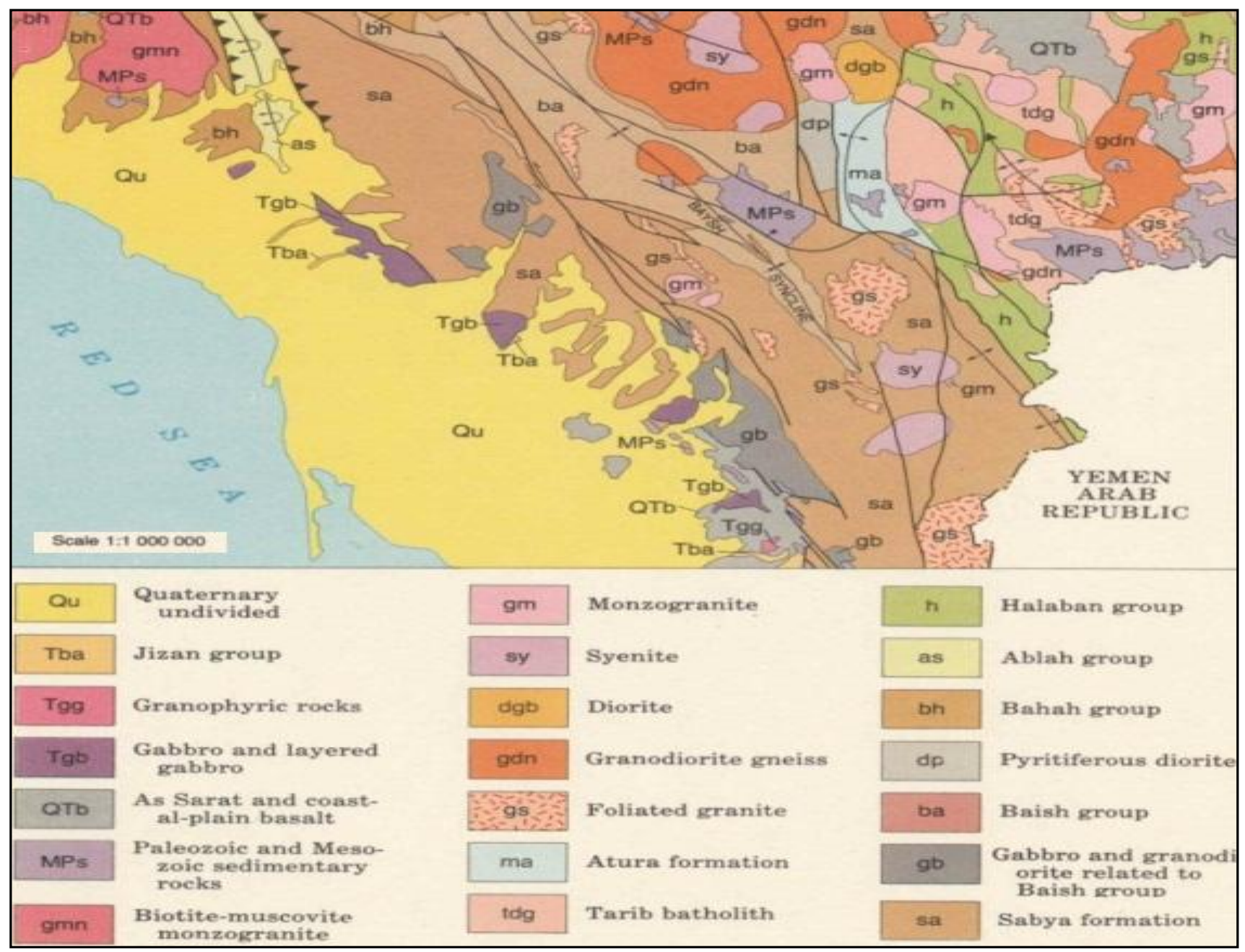

Figure 1. Geologic map of Jizan area showing the different encountered rock units ranging in age from Pre-Cambrian to Quaternary (Fairer, 1985).

large number of promised geothermal collectives and hot springs are allocated along the coastal parts of Gulf of Suez of Egypt, the Eastern coasts of the East African Rift countries and the southwestern coasts of Saudi Arabia. These springs owe their existence to tectonic (or volcanic) heating associated with the opening of the Red Sea/Gulf of Suez rift (Boulos, 1990; Lashin, 2007; Lashin and Al Arifi, 2010). So, studying these geothermal targets as possible sources for renewable energy in Saudi Arabia is of prime interest.

Jizan area is located in the southwest part of Saudi Arabia between longitudes $42.0-43.8^{\circ} \mathrm{E}$ and latitudes $16.5-17.0^{\circ} \mathrm{N}$ with a square area of $13,500 \mathrm{~km}^{2}$. It constitutes part of Arabia shield which is a part of the Precambrian crustal plate and consists of igneous, basalts, diorites, gabbros and mica-schist. During the tertiary period, the shield was separated from the adjacent African shield by a rift of earths' crust that is currently occupied by the Red Sea. The geology of Jizan area is mainly divided into two main features. The near shore deposits which include many valleys draining towards the sea and the crystalline basement (granite) and metamorphic rocks in the eastern portions of Jizan which include a number of promised hot springs. In the absence of lithologic or structural units more favourable to the existence of reservoirs, all evidences indicated that, these granite units' acts as a reservoir, and that the water rises to the surface either through fractures or lithologic/structural discontinuities; that is, fracture separating the granite unit from its metamorphic or crystalline host rock (Al Dayel, 1988). The geological map of Jizan area (Figure 1) exhibits rock units ranging in age from Pre-Cambrian to Quaternary. The Precambrian Basement Complex consists mainly of three rock units, that is: Sabya Formation, the Baish group and Halaban group. Figure 2 shows that the main recognized geothermal anomalies (Al Ardah, Al Khouba and Bani Malik) are more closely located to the east, away from 


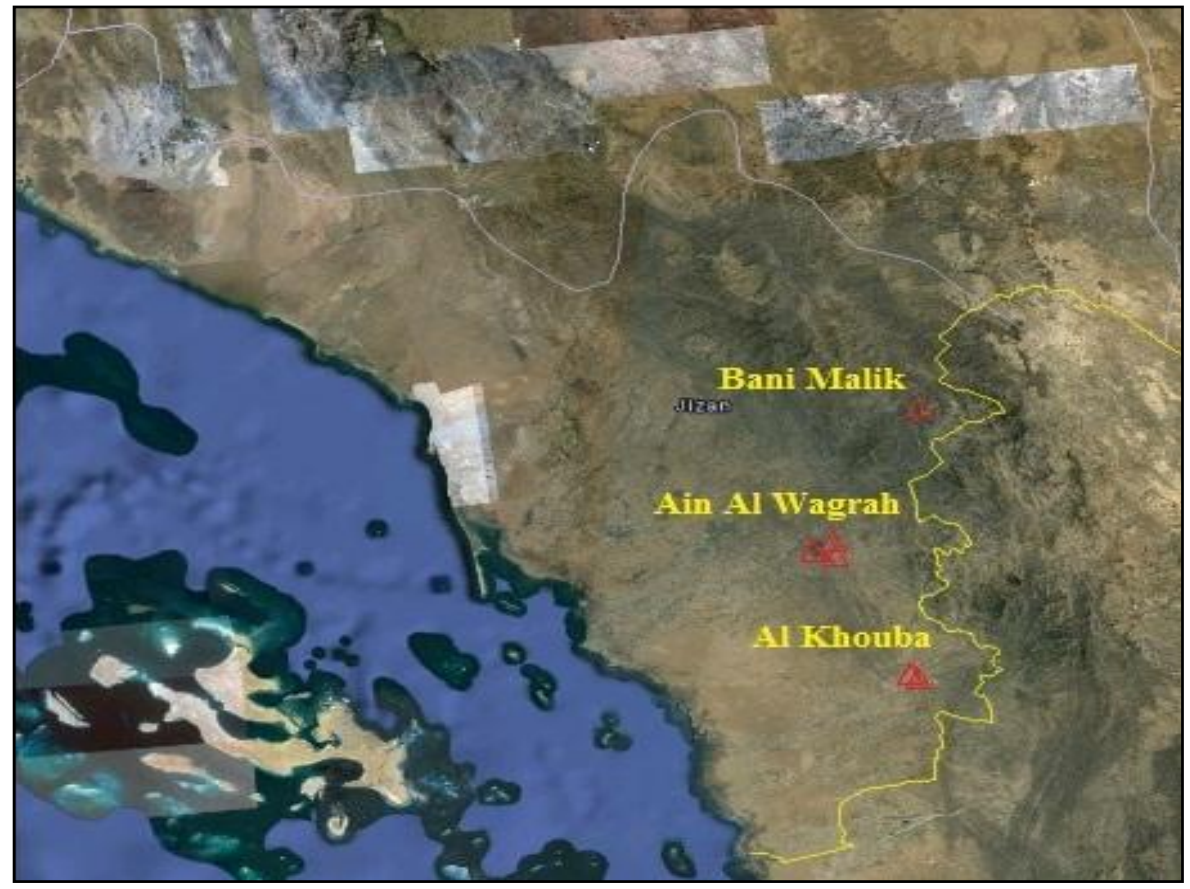

Figure 2. Land sat map showing the location of the main detected geothermal targets in Jizan area.

the coastal plain in areas of high and complicated topographic nature, and originating from hard crystalline rocks.

Remote sensing (RS) and image processing methods are very attractive, fast and reliable tools for various applications and management (Sonka et al., 1993; Lillesand and Kiefer, 1994). Nowadays, they are the most commonly used technologies in applied studies, many research and applications areas (Jeffrey and John, 1990). Digital and remote sensing data combined with spatial analysis tools embedded in a Geographical Information System (GIS), provided a framework for implementing the stratification techniques of watershed analysis required to quantify the effect of land cover on hydrology and geomorphology of Jizan watersheds.

Many water geo-thermometers were developed from the mid-1960s to the mid-2010s. The most important ones are the Silica, $\mathrm{Na} / \mathrm{K}$ and $\mathrm{Na}-\mathrm{K}-\mathrm{Ca}$ geo-thermometers. Some other geo-thermometers are based on the $\mathrm{Na} / \mathrm{Li}, \mathrm{Li} / \mathrm{Mg}, \mathrm{K} / \mathrm{Mg}$ ratios and $\mathrm{Na}-\mathrm{K}-\mathrm{Mg}$ relationships. Many workers had dealt with using the geo-thermometers for subsurface formation temperature studies. The most important works are those done by Fournier and Rowe (1966), Ellis and Mahon (1977), Fournier (1977), Fournier and Potter (1982), Swanberg et al. (1983), Arnorsson et al. (1983, 1985), Arnorsson and Stefansson (1999), and Arnorsson et al. (2002). The geo-thermometers are usually used to estimate some important geothermal parameters such as heat flow, discharge enthalpy and subsurface formation temperature.

The aim of this study is to shed light on the possible potentiality of the geothermal resources at Jizan area, through analyzing the available satellite images and interpreting the results obtained from the different geothermometers, based on the chemical analyses of water samples collected from the hot springs and surrounding wells.

\section{METHODOLOGY}

The utilized methodologies in this work are mainly of two types. The first approach is based on a detailed GIS and satellite image analysis, where a number of Land sat ETM 5 and 7 and Spot 5 satellite images are analyzed. The objectives of such analysis are: 1) to locate the different geothermal collectives and hot springs, in addition to their surrounding water wells, 2) to identify the topographic elevations, the prevailing wadis, main pathways, and entrances for the hot springs, 3) to determine the drainage pattern and 4) to enhance a digital elevation model (DEM) for the study area. The second approach depends on enhancing a geothermometer study based on the chemical analyses of many water samples collected from hot springs and some neighbouring wells closely surrounding them. Water samples are analyzed for the major cations and anions, as well as for minor elements. The $\mathrm{pH}$ of each sample, its total dissolved salts and electric conductivity are also measured. Temperature sensor is used for measuring the insitu temperature of the hot springs (Table 1). A number of ternary $\left(\mathrm{Cl}-\mathrm{SO}_{4}-\mathrm{HCO}_{3}\right)$ and Giggenbach (Na-K-Mg) diagrams are constructed for the different encountered hot springs to classify the thermal water on the basis of major anions and cations and to indicate the prevailing subsurface thermal conditions.

A variety of geo-thermometers with good efficiency and with low geothermal systems are selected to measure the needed geothermal parameters. Theoretically, geo-thermometers can be used as indicators for both high temperature $\left(T>150^{\circ} \mathrm{C}\right)$ and low 
Table 1. Summaries of the co-ordinates and some field measurements of the different hot springs encountered at Jizan area.

\begin{tabular}{|c|c|c|c|c|c|c|c|}
\hline Location & Hot spring & Co-ordinates & Surface Temp. $\left({ }^{\circ} \mathrm{C}\right)$ & Elev. (M) & $\mathrm{pH}$ & TDS (ppm) & $\mathrm{EC}\left(\mu \mathrm{Scm}^{-1}\right)$ \\
\hline & Ain Al Wagrah-1 & $\begin{array}{l}17^{\circ} 02.124^{\prime} \\
42^{\circ} 59.374^{\prime}\end{array}$ & 44 & 179.5 & 7.7 & 3592 & 5987 \\
\hline & Ain Al Wagrah-2 & $\begin{array}{l}17^{\circ} 02.130^{\prime} \\
42^{\circ} 59.370^{\prime}\end{array}$ & 45 & 180.7 & 7.5 & 8815 & 14692 \\
\hline & Ain Al Wagrah-3 & $\begin{array}{l}17^{\circ} 02.156^{\prime} \\
42^{\circ} 59.360^{\prime}\end{array}$ & 57 & 178.0 & 7.2 & 3072 & 5120 \\
\hline \multirow[t]{4}{*}{ Al Ardah } & Ain Al Wagrah-4 & $\begin{array}{l}17^{\circ} 02.160^{\prime} \\
42^{\circ} 59.365^{\prime}\end{array}$ & 57 & 178.0 & 7.2 & 3076 & 5127 \\
\hline & Ain Al Wagrah-5 & $\begin{array}{l}17^{\circ} 02.165^{\prime} \\
42^{\circ} 59.370^{\prime}\end{array}$ & 45 & 178.0 & 7.2 & 3135 & 5225 \\
\hline & Ain Al Wagrah-6 & $\begin{array}{l}17^{\circ} 02.960^{\prime} \\
42^{\circ} 59.390^{\prime}\end{array}$ & 61 & 178.8 & 7.0 & 3066 & 5110 \\
\hline & Ain Al Wagrah-7 & $\begin{array}{l}17^{\circ} 03.443^{\prime} \\
42^{\circ} 57.830^{\prime}\end{array}$ & 57 & 167.5 & 7.6 & 2088 & 3480 \\
\hline Al Khouba & Ain Khulab & $\begin{array}{l}16^{\circ} 45.854^{\prime} \\
43^{\circ} 07.769^{\prime}\end{array}$ & 76 & 160.0 & 7.4 & 2510 & 4183 \\
\hline Bani Malik & Bani Malik & $\begin{array}{l}17^{\circ} 16^{\prime} 11.2^{\prime \prime} \\
43^{\circ} 13^{\prime} 08.6^{\prime \prime}\end{array}$ & 45 & 647.5 & 7.3 & 1290 & 2150 \\
\hline
\end{tabular}

temperature geothermal systems $\left(T<150^{\circ} \mathrm{C}\right)$. Almost all the hot springs to be studied have a surface temperature less than $150^{\circ} \mathrm{C}$ with an average range of $70-80^{\circ} \mathrm{C}$. The following are the main selected geo-thermometers which are utilized in this study:

\section{Quartz (Silica) Geo-thermometers}

$\mathbf{T}_{1}\left({ }^{\circ} \mathrm{C}\right)=\frac{1309}{5.19-\log Q z}-273.15$

Range of ${ }^{\circ} \mathrm{C}: 25-250$

$\mathrm{T}_{2}\left({ }^{\circ} \mathrm{C}\right)=42.198+0.28831 Q z-3.6686 * 10^{-4} Q z^{2}+3.1665^{*} 10^{-7} Q z^{3}+77.034 \log Q z$

Range of ${ }^{\circ} \mathrm{C}: 0-350$

\section{Na-K-Ca Geo-thermometers}

$$
\begin{gathered}
\mathrm{T}_{1}\left({ }^{\circ} \mathrm{C}\right)=\frac{933}{0.993+\log (\mathrm{Na} / \mathrm{K})}-273.15 \\
\text { Range of }{ }^{\circ} \mathrm{C}: 25-250
\end{gathered}
$$

$$
\mathrm{T}_{2}\left({ }^{\circ} \mathrm{C}\right)=\frac{1647}{\log (\mathrm{Na} / \mathrm{K})+\beta \log \left(\mathrm{Ca}^{0.5} / \mathrm{Na}\right)+2.24}-273.15
$$

ICEBOX-Watch, 2.1 software was used for conducting the necessary calculations. The scientific procedures followed in these analyses are based mainly on the work of Fournier and Rowe (1966), Fournier (1977), Fournier and Potter (1982), Arnorsson $(1985,2000)$ and Arnorsson et al. (2002). The most important parameters to be concluded from this analysis are the chemical characteristics of the deep fluid, its actual subsurface temperature, discharged enthalpy and heat flow.

\section{INTERPRETATIONS OF DATA}

\section{Land sat and satellite images}

Figures 3 to 6 exhibit the slope, drainage pattern and basin, the digital elevation model and the topographic maps of Jizan area. These maps illustrate the location of the different studied hot springs and their surrounding water wells. Three main locations with good thermal activities are detected at Jizan area, namely: Al Ardah, Al Khouba and Bani Malik areas. The slope and digital elevation maps showed that hot springs encountered Al Ardah, are located in medium to low lands with little slopes, surrounded by a 


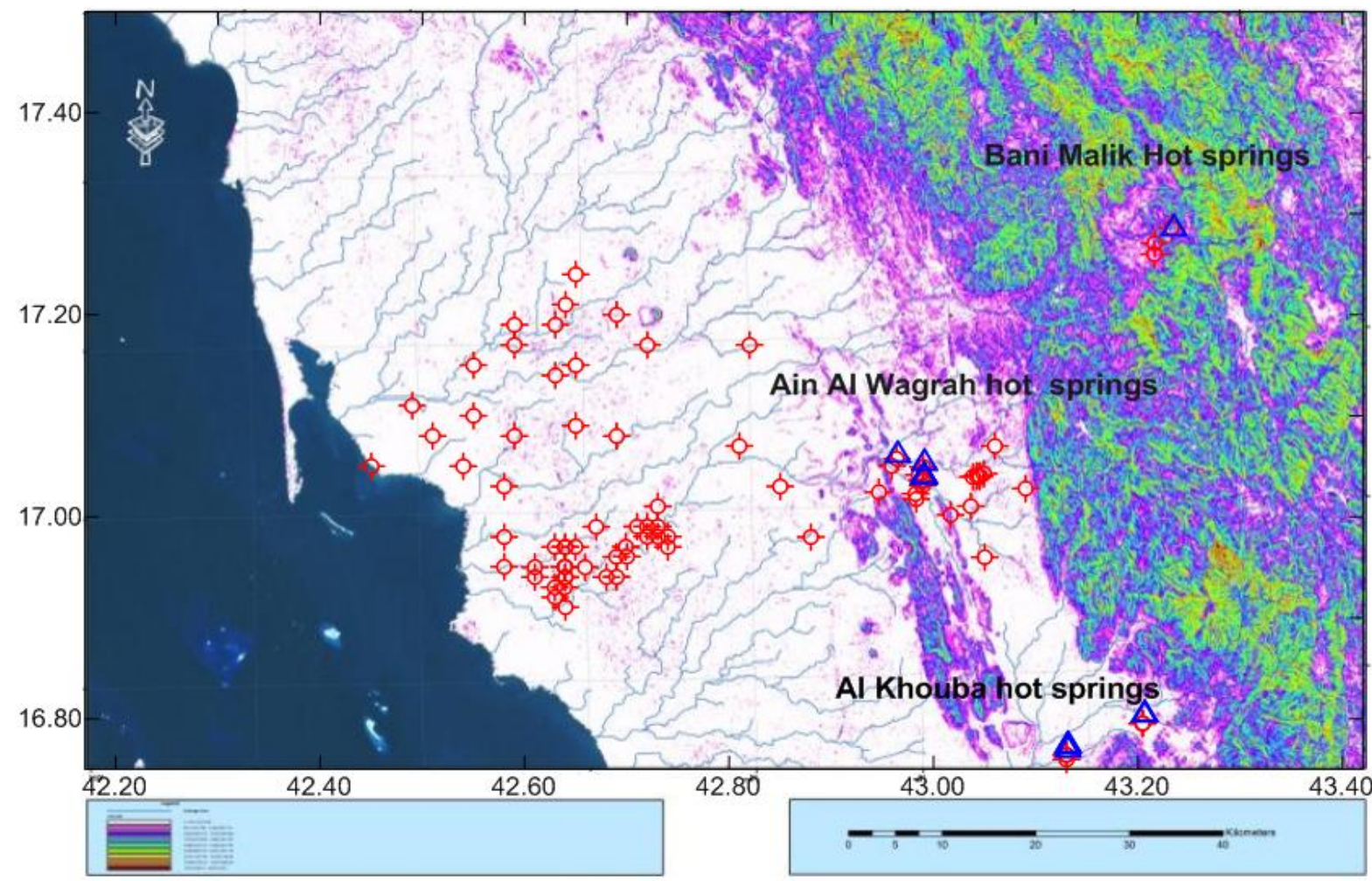

Figure 3. Slope map of Jizan area showing east-west decrease of the slope towards the coastal parts.

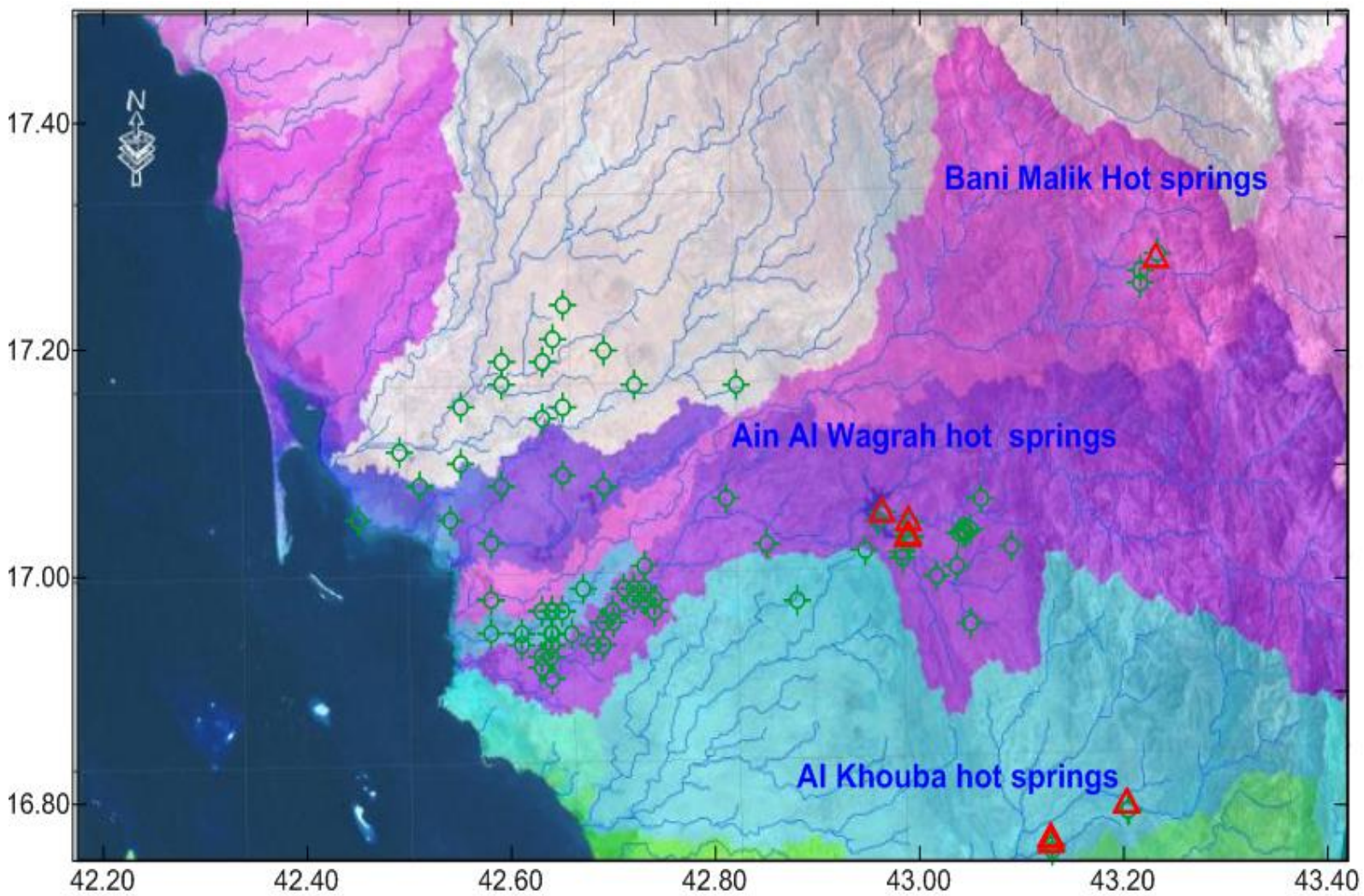

Figure 4. Drainage pattern and basin map of Jizan area illustrating the presence of different basins of dendertic pattern. 


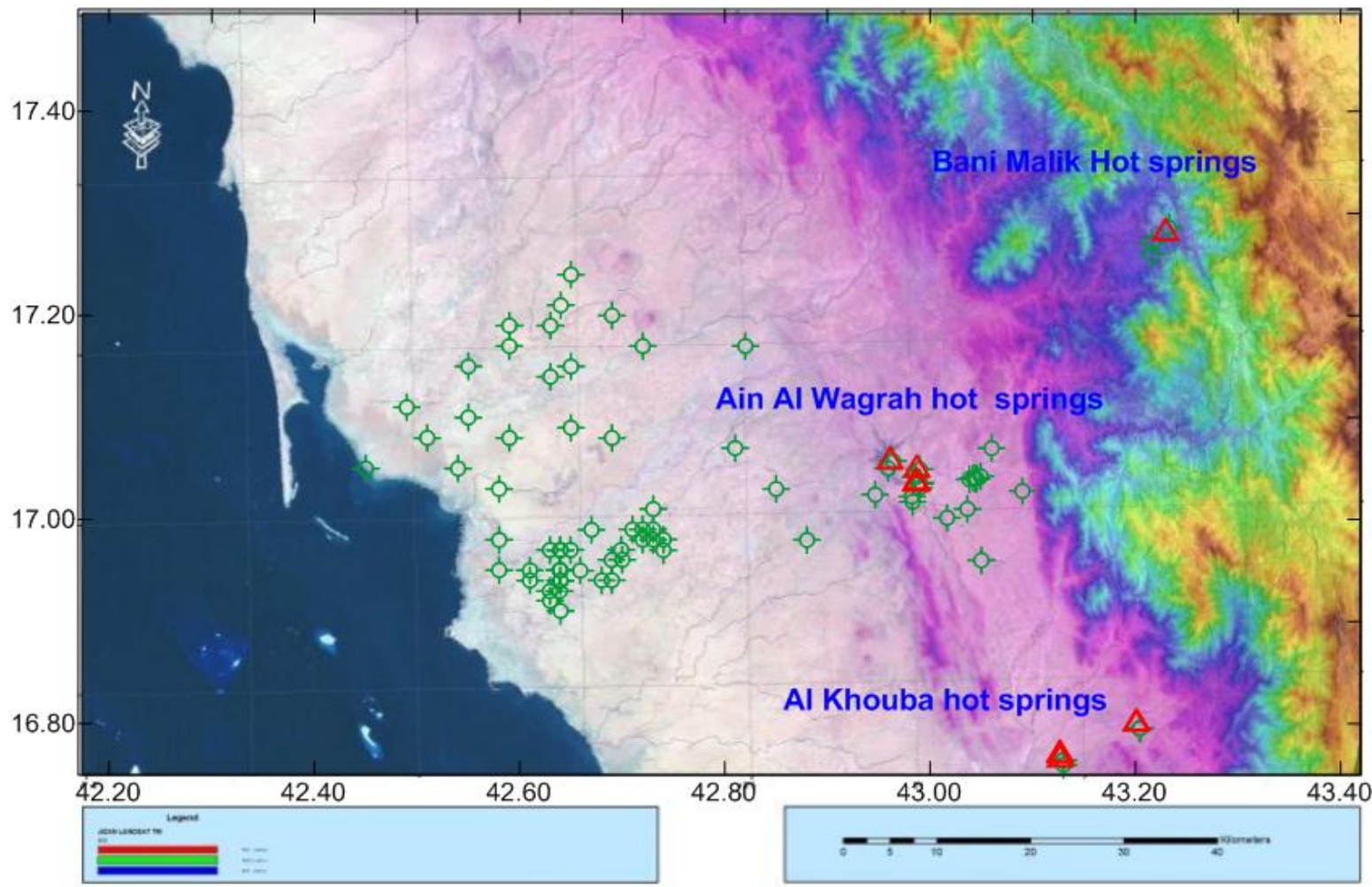

Figure 5. Digital elevation model (DEM) map of Jizan illustrating high areas in the eastern portions.

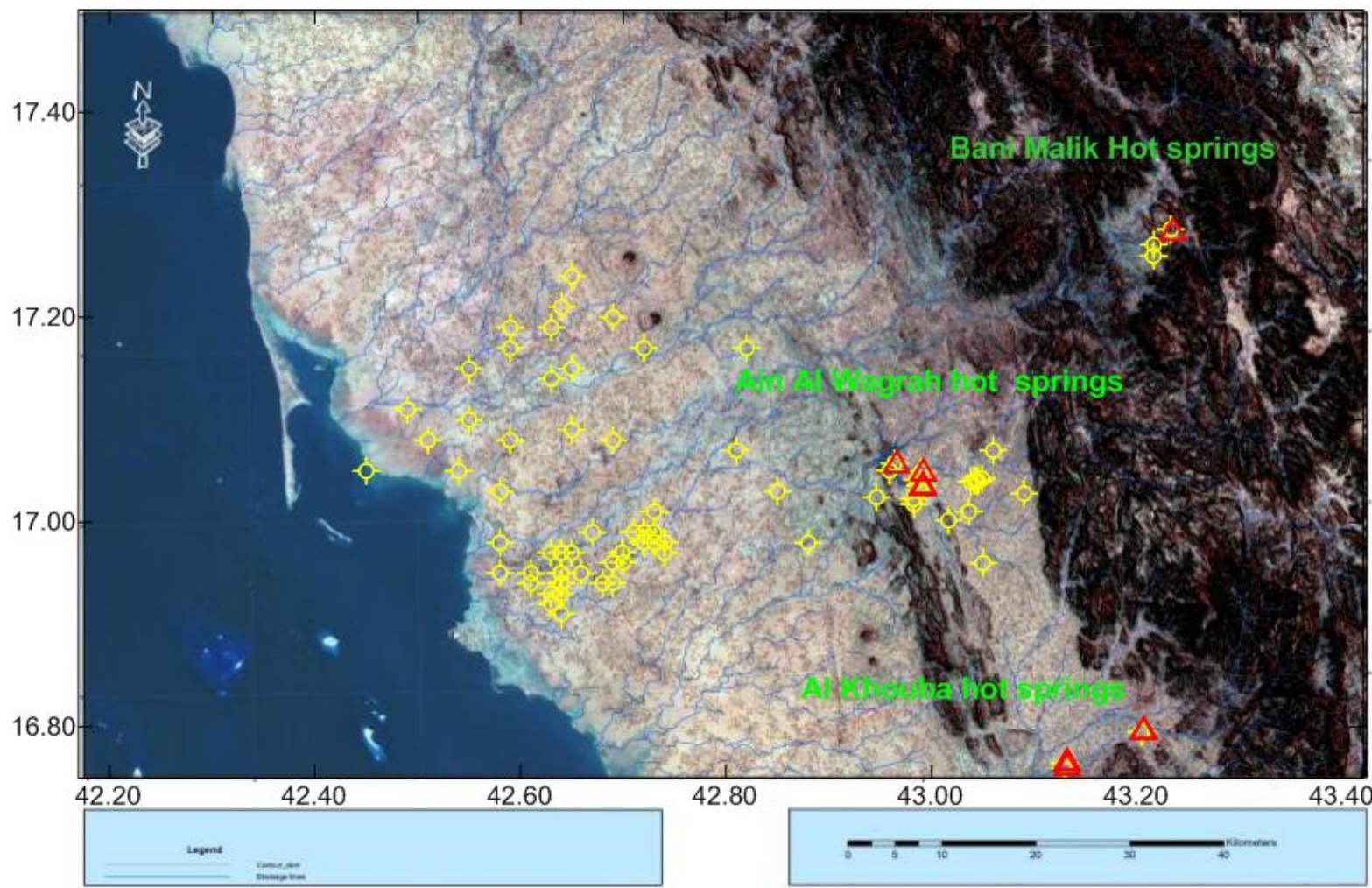

Figure 6. Topographic map of Jizan area indicating complicated ridges in the eastern parts compared with the simple coastal plains in the west. 


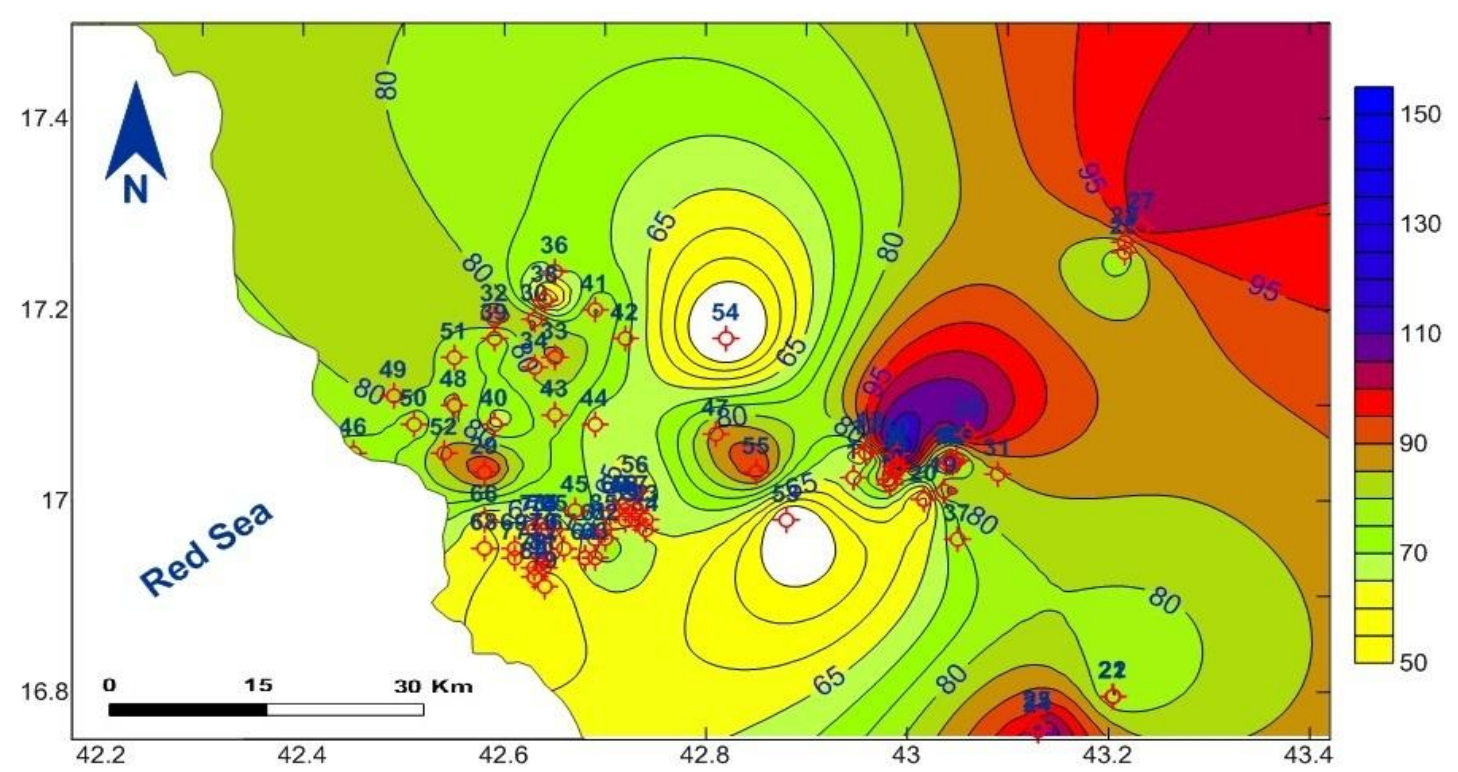

Figure 7. The subsurface temperature distribution map of Jizan area.

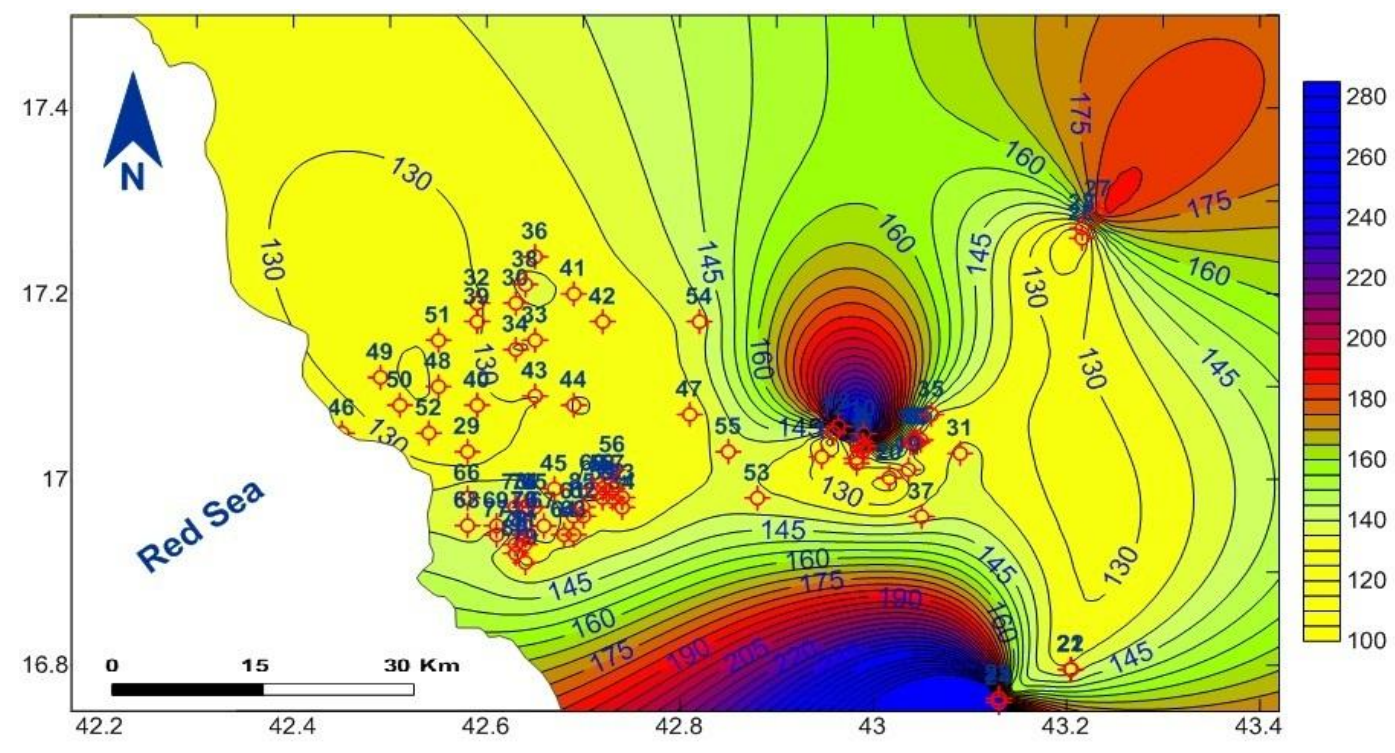

Figure 8. The discharge enthalpy distribution map of Jizan area.

ridge of high basement rocks. The topographic elevation above sea level is not more than $181 \mathrm{~m}$ and the slope angle is less than $20^{\circ}$. Seven hot springs are recognized in this area, out of them, six are located around the Dam Lake and one behind it. On the other hand, one main hot spring is found at Al Khouba area (Ain Khulab) which is characterized by its low land $(160 \mathrm{~m}$ asl), gentile slopes and uncomplicated nature.

Finally, the hot springs of Bani Malik area are located to the north east of Jizan in a very tough and high slope area. The topographic elevation is more than $645 \mathrm{~m}$ and the slope angle reaches up to $45^{\circ}$. The basin and drainage pattern map, illustrates that these three geothermal systems are located in different drainage basins, with a prevailing dendritic patterns.

\section{Geothermometry}

Based on the results of the geothermometer data, the main petrothermal parameters of interest (subsurface formation temperature, discharge enthalpy and heat flow) are interpreted. Figures 7 to 9 exhibit the lateral distribution maps of these parameters. The subsurface temperature map (Figure 7) showed the normal regular distribution of the subsurface temperature for the water wells surrounding the hot springs. The temperature range for these wells 


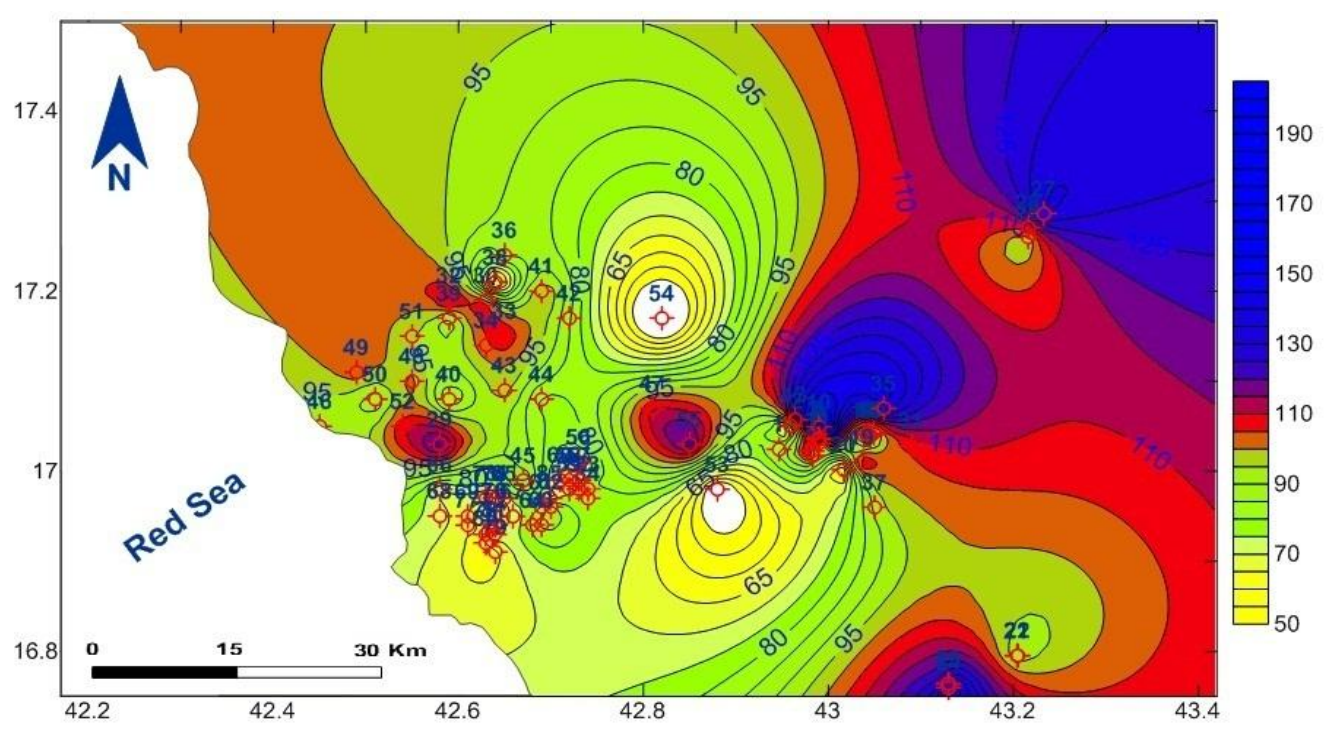

Figure 9. The heat flow distribution map of Jizan area.

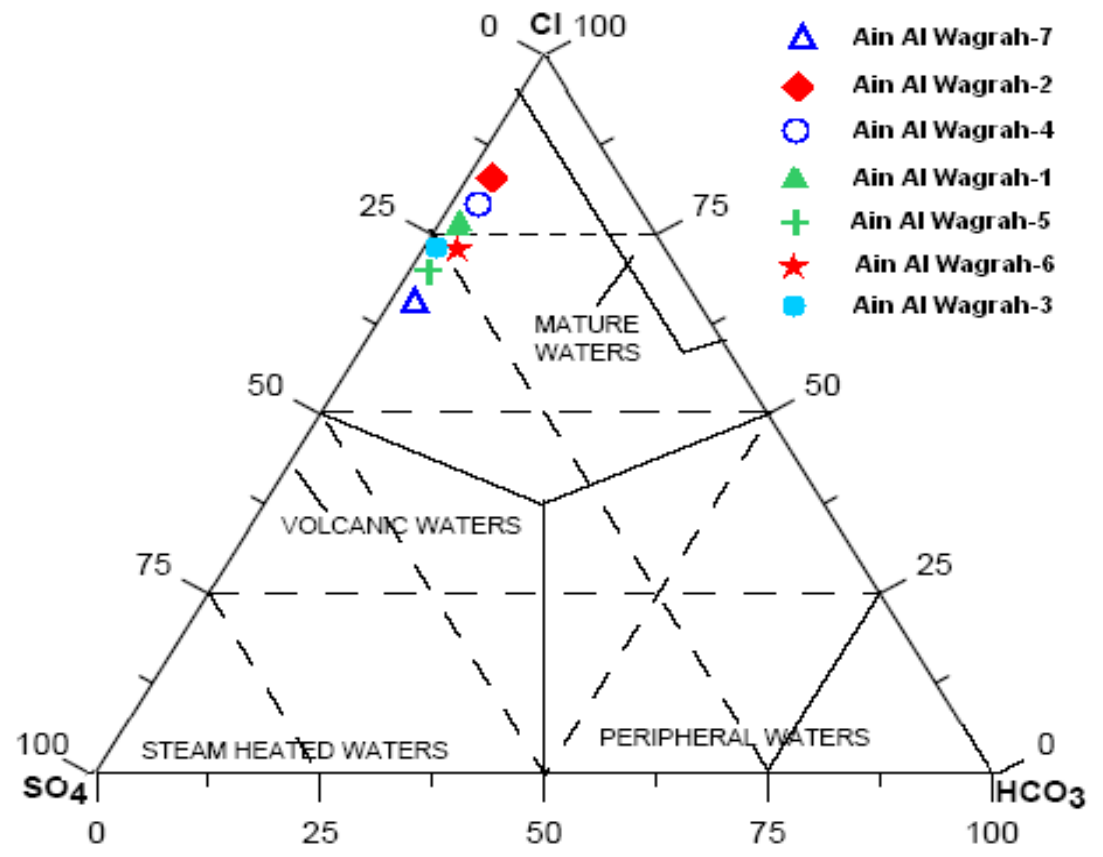

Figure 10. Water type classification of the hot springs using $\mathrm{CL}-\mathrm{SO}_{4}-\mathrm{HCO}_{3}$ diagram, Al Ardah area, Jizan.

are $38-90^{\circ} \mathrm{C}$. On the other hand, a much higher subsurface temperature range $\left(95\right.$ to $\left.150^{\circ} \mathrm{C}\right)$ is indicated for the hot springs. This was clearly observed by the dense blue-to-red coloured contour lines, especially in the areas occupied by Ain Al Wagrah, Al Khouba and Bani Malik hot springs. The maximum value of subsurface temperature $\left(151.4^{\circ} \mathrm{C}\right)$ was exhibited by Ain Al Wagrah2 hot spring.

The discharge enthalpy map (Figure 8) assigns high enthalpy values for the hot springs $(180-380 \mathrm{Kj} / \mathrm{kg})$ and low enthalpy values for the surrounding water wells, with a general trend of decreasing towards the shore line $(100-160 \mathrm{Kj} / \mathrm{kg})$. The heat flow distribution map ensures the same results concluded from the discharge enthalpy and subsurface temperature data. Good and high heat flow values are recognized in the areas of Ain Al Wagrah, Al Khouba and Bani Malik hot springs (Figure 9). The recorded heat flow values in these areas reach higher margin up to $263.3 \mathrm{~mW} / \mathrm{M}^{2}$.

\section{Classification of thermal fluids and water type}

Figures 10 to 12 show the $\mathrm{Cl}-\mathrm{SO}_{4}-\mathrm{HCO}_{3}$ diagrams of the different hot springs encountered at $\mathrm{Al}$ Ardah, Al Khouba and Bani Malik 


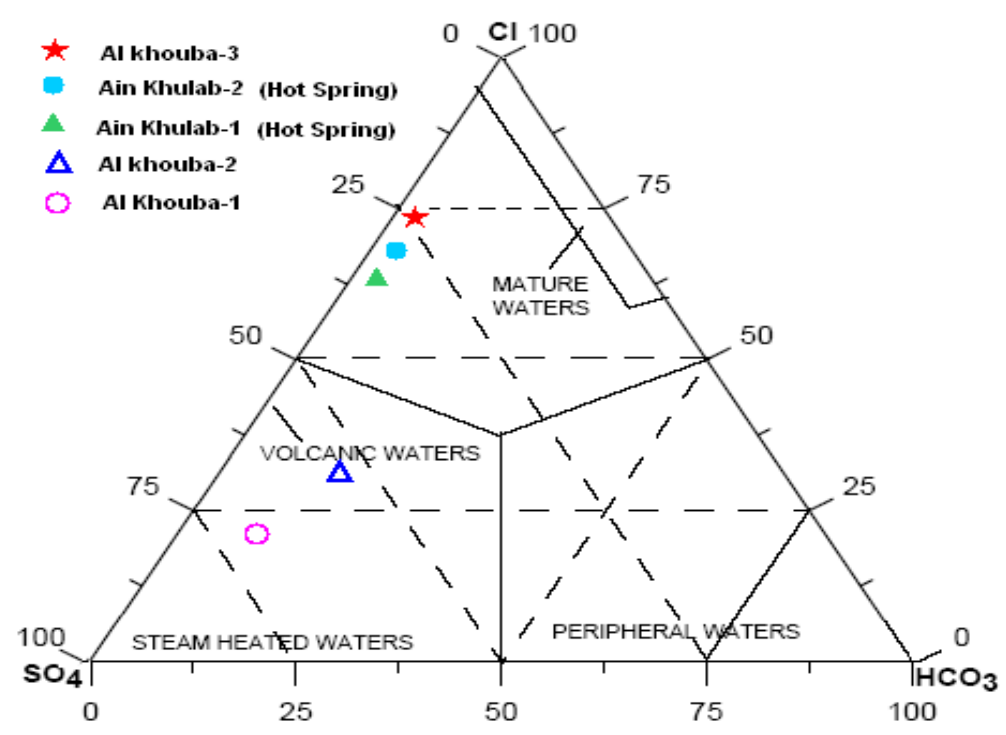

Figure 11. Water type classification of the hot springs using $\mathrm{CL}-\mathrm{SO}_{4}$ $\mathrm{HCO}_{3}$ diagram, Al Khouba area, Jizan.

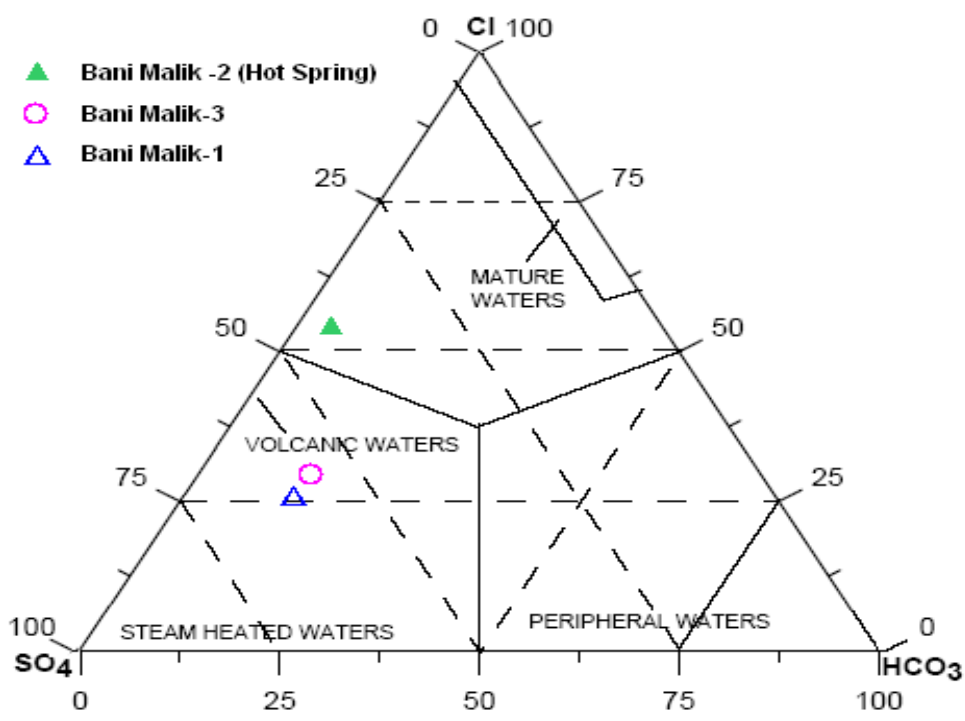

Figure 12. Water type classification of the hot springs using $\mathrm{CL}-\mathrm{SO}_{4}$ $\mathrm{HCO}_{3}$ diagram, Bani Malik area, Jizan.

areas. The different water samples collected from the studied hot springs and some water wells neighboring them are plotted in these diagrams. Regarding the diagrams, different types of thermal waters can be distinguished, such as: mature $(\mathrm{Cl})$ waters, $\mathrm{SO}_{4}$ dominated waters and peripheral $\left(\mathrm{HCO}_{3}\right)$ waters.

Most of the data points are located in the mature water area along the $\mathrm{Cl}-\mathrm{SO}_{4}$ line and are found to be more close to the chlorine point. This indicates the dominance of the chlorine and sulphate anions on the expanse of the bicarbonate group. The low $\mathrm{HCO}_{3}$ associated with high sulphate indicates near surface process including oxidation such as incursion of shallow ground water. Two data points belonging to two water wells in Al Khouba area are clustered at the volcanic water area with increasing content of the sulphate content. Figure 12 exhibits the $\mathrm{Cl}-\mathrm{SO}_{4}-\mathrm{HCO}_{3}$ diagram of Bani Malik area.
The data point of the hot spring (Bani Malik-2) is located at the mature water area, while the clusters of other water wells that are closely found to the hot spring are located in the volcanic water area.

\section{Giggenbach diagrams}

Giggenbach $(1986,1988)$ introduced graphical techniques for the evaluation of water-rock interaction conditions by the use of $\mathrm{Na}, \mathrm{K}$, $\mathrm{Mg}$ and $\mathrm{Ca}$ contents of discharge water and a derivation of the geothermal solute equilibrium using $\mathrm{Na}-\mathrm{K}-\mathrm{Mg}-\mathrm{Ca}$ geo-indicators. In this study, the $\mathrm{Na}, \mathrm{K}, \mathrm{Mg}$ diagram is used to indicate the subsurface geothermal condition at which the dissolved ions of the surface upcoming thermal fluids are originated. Figures 13, 14 and 


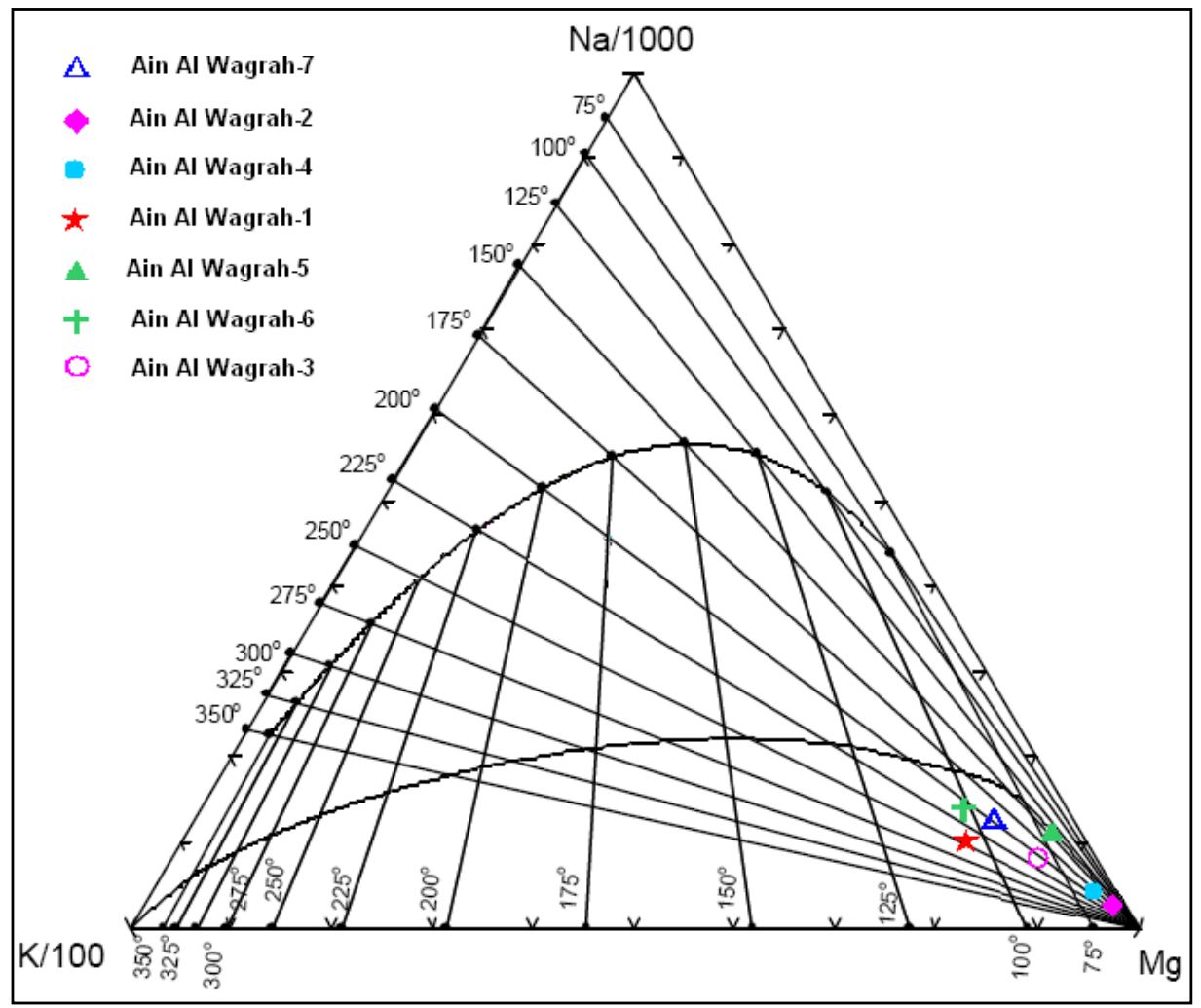

Figure 13. Giggenbach diagram for the thermal fluids of Al Ardah area, Jizan.

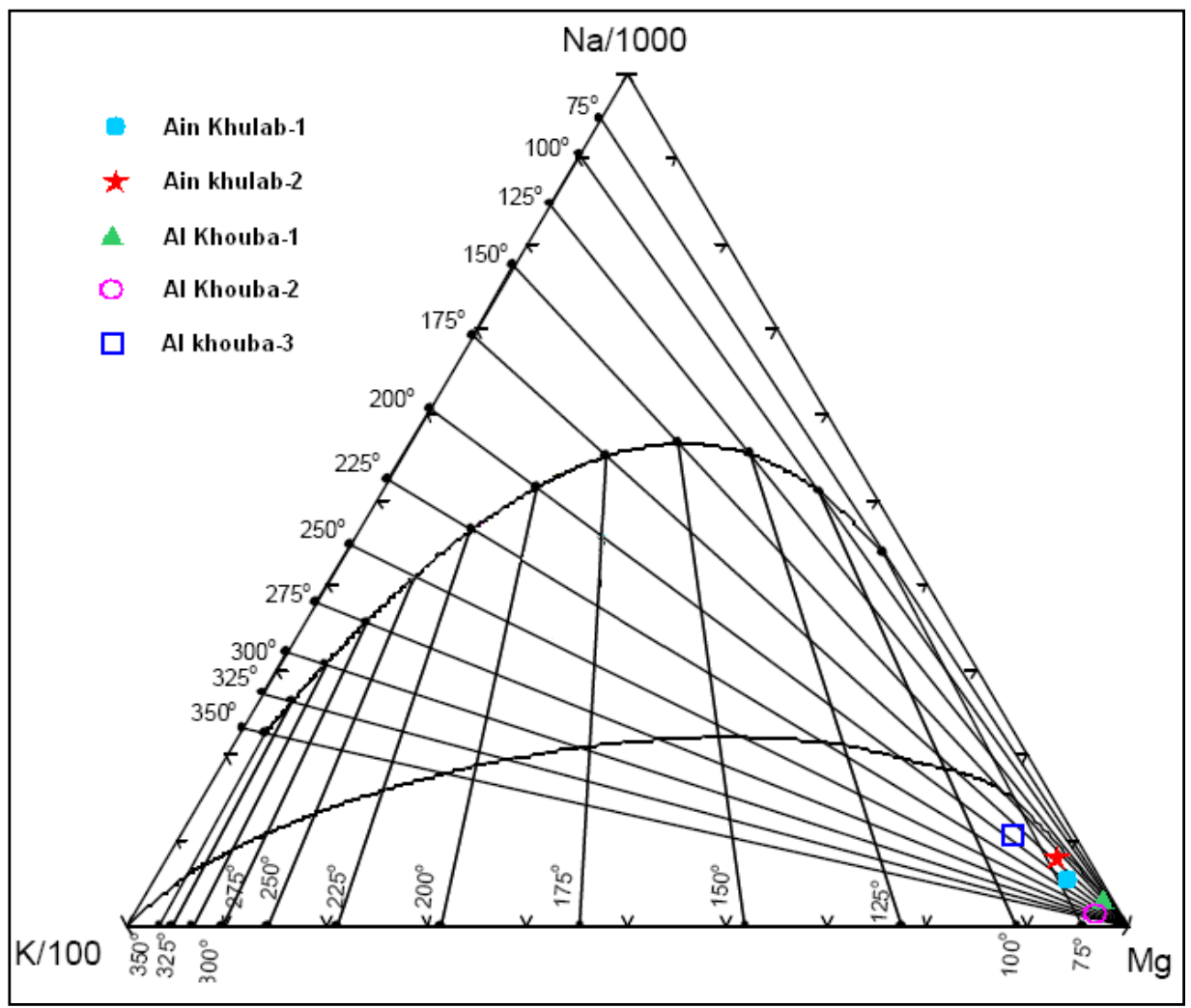

Figure 14. Giggenbach diagram for the thermal fluids of Al Khouba area, Jizan. 


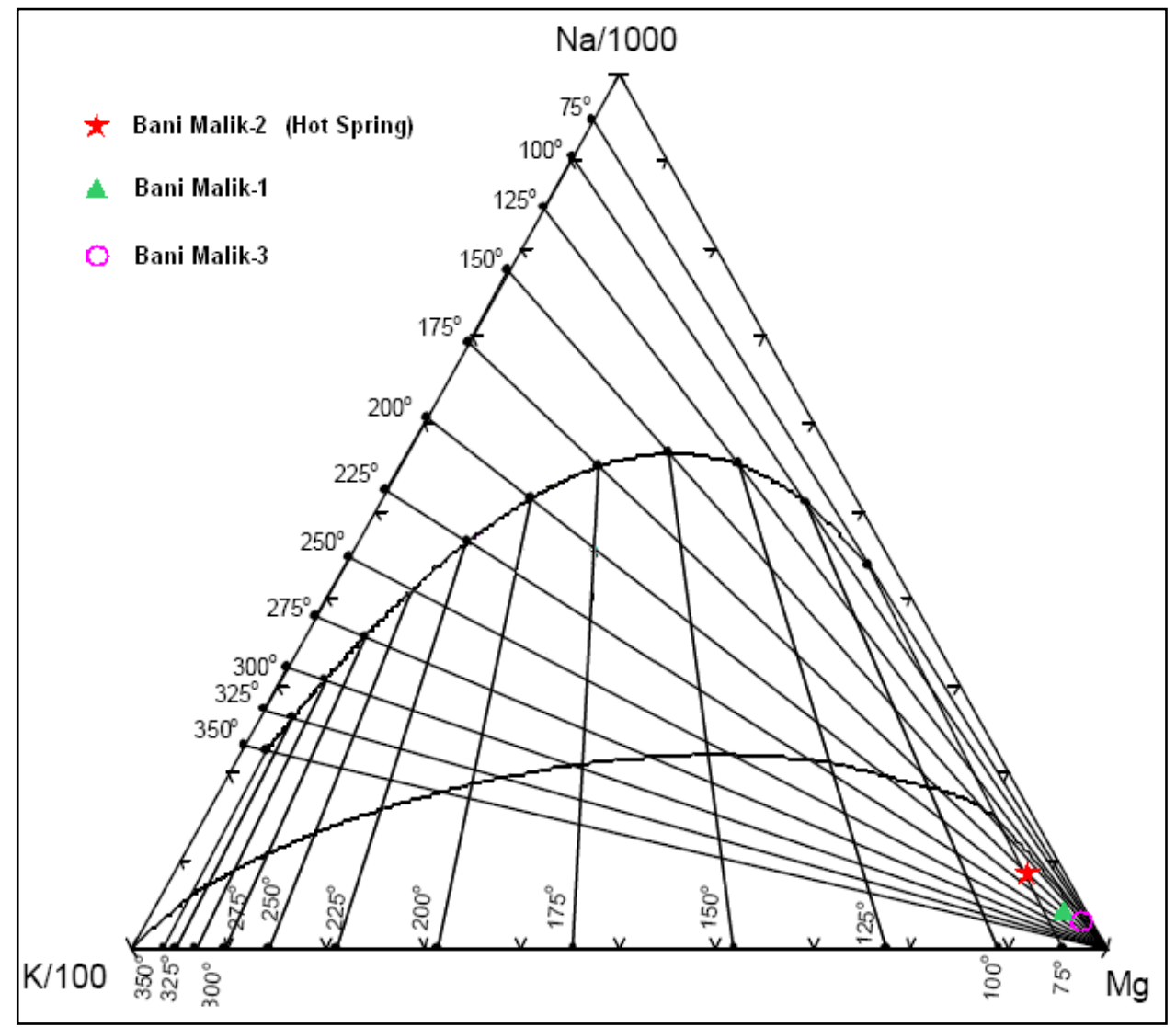

Figure 15. Giggenbach diagram for the thermal fluids of Bani Malik area, Jizan.

15 represent the constructed $\mathrm{Na}, \mathrm{K}, \mathrm{Mg}$ Giggenbach diagrams for the hot springs at Jizan area.

The data points of the thermal fluids of Al-Ardah area (Figure 13) are mainly located between the temperature lines of 200 and $250^{\circ} \mathrm{C}$, along the $\mathrm{Na}-\mathrm{K}$ classifying line, just behind the $100^{\circ} \mathrm{Mg}-\mathrm{K}$ temperature line and more closely to the $\mathrm{Mg}$ point. Two clusters (Ain Al wagrah-1 and Ain Al wagrah-6) are located in the front of the $100^{\circ} \mathrm{Mg}-\mathrm{K}$ temperature line assigning high subsurface conditions of these points as indicated by the K-Mg indicator. Figures 14 and 15 , on the other hand, showed the Giggenbach diagrams of Al Khouba and Bani Malik areas. All data points are located behind the $75^{\circ}$ $\mathrm{Mg}-\mathrm{K}$ temperature line and between the 200 and $220^{\circ} \mathrm{Na}-\mathrm{K}$ temperature lines. Only one exception is represented by Al Khouba3 well which is located between the 75 and $100^{\circ} \mathrm{Mg}-\mathrm{K}$ temperature lines.

\section{DISCUSSION AND CONCLUSIONS}

The purpose of this study is to investigate the geothermal potentiality of the available geothermal resources located at the southwestern parts of Saudi Arabia and determine the characteristics of the encountered thermal waters, by applying them on Jizan hot springs. The procedures followed in this study depend mainly on analyzing the available land sat and satellite images data, as well as performing a detailed geothermometer study, based on the chemical analyses of many water samples collected from the hot springs and their surrounding wells. A number of ternary and Giggenbach diagrams are constructed in order to determine the water type and evaluate the subsurface prevailing thermal regimes.

Regarding the geothermal potentiality of Jizan area, three promised geothermal locations are found. The first is located at Al-Ardah area, east of Abu Arish and more closely to and/or around the Dam Lake. Seven hot springs are encountered in this area (Ain Al Wagrah-1 to -7) with a surface temperature range of $43-61^{\circ} \mathrm{C}$. The second geothermal target is located at the southeastern of Jizan at Al Khouba area, where one main hot spring of high surface temperature $\left(76^{\circ} \mathrm{C}\right)$ and fair to good flow rate is found. The slope, topographic and digital elevation maps showed that, these hot springs are located in medium to low lands with little slopes, surrounded by a ridge of high basement rocks. The third geothermal anomaly is located to the northeast of Jizan province, in a very high and more complicated-topographic area (Bani Malik) and originated from low-temperature $\left(45^{\circ} \mathrm{C}\right)$ system of highly fractured basement and metamorphic rocks.

Based on the geothermometer data, good petrothermal characters (subsurface temperature, discharge enthalpy and heat flow) are assigned for these hot springs. The recognized petro-thermal ranges are found to 
be $95-150^{\circ} \mathrm{C}$ for subsurface temperature, $180-255 \mathrm{Kj} / \mathrm{Kg}$ for discharge enthalpy and $120-210 \mathrm{~mW} / \mathrm{M}^{2}$ for heat flow. The constructed ternary diagrams assigned mature water type with the dominance of chlorine and sulphate anions on the expanse of the bicarbonate group for the hot springs located at $\mathrm{Al}$ Ardah and Al Khouba areas. However, some volcanic water types with abundant content of the sulphate are detected also in Al Khouba area. The thermal water of Bani Malik hot springs, on the other hand, exhibits a mature nature, while a volcanic water type was assigned for the neighbouring water wells. Furthermore, the results obtained from the constructed $\mathrm{Na}, \mathrm{K}, \mathrm{Mg}$ Giggenbach diagrams are matched with those concluded from the detailed geothermometer analyses. The thermal characteristics of the fluids of the studied hot springs mainly ranged between temperature lines $200-250^{\circ} \mathrm{C}$ and $200-220^{\circ} \mathrm{C}$ (along the $\mathrm{Na}-\mathrm{K}$ classifying line) for Al-Ardah area and for both Al Khouba and Bani Malik areas, respectively.

From the concluded results, it is believed that the investigated geothermal resources have the potential of been used in the future. Therefore, we recommend the continuity of the work to the next phase, with detailed geophysical surveys (seismic and electric) to discover the subsurface configuration of the encountered geothermal targets.

\section{ACKNOWLEDGEMENT}

This work was funded and completely supported by the National Plan for Science, Technology and Innovation program (NPST), King Saud University, project number 10-ENE1043-02.

\section{REFERENCES}

Ahmed K (1994). Renewable energy technologies: A Review of the status and costs of selected technologies. World Bank Technical Energy Series. p. 240.

Al Dayel M (1988). Geothermal resources in Saudi Arabia. Geothermics, 17(2/3): 465-476.

Alnatheer $O$ (2007). Corrigendum to the potential contribution of renewable energy to electricity supply in Saudi Arabia. Energy Policy, 35(12): 2298-2312.

Arnorsson S (1985). The use of mixing models and chemical geothermometers for estimating underground temperatures in geothermal systems. J. Volcanol. Geothermal Res., 23: 299-335.

Arnorsson S (2000). Isotopic and chemical techniques in geothermal exploration, development and use: Sampling methods, data handling and interpretation. Introductory course, GTP. IS-108, Reykjavik, Iceland, p. 199

Arnorsson S, Stefansson A (1999). Assessment of feldspar solubility constants in water in the range 0 to $350^{\circ} \mathrm{C}$ at vapour saturation pressures. Am. J. Sci., 299: 173-209.

Arnorsson S, Gunnlaugsson E, Svavarsson H (1983). The chemistry of thermal waters in Iceland. II. Mineral equilibria and independent variables controlling water compositions. Geochim. Cosmochim. Acta, 47: 547-566.
Arnorsson S, Gunnarson I, Stefansson A, Andresdottir A, Sveinbjornsdottir AE (2002). Major element chemistry of surface and ground waters in basaltic terrain, N-Iceland. Geochim. Cosmochim. Acta, 66: 4015-4046.

Boulos F (1990). Some aspects of the geophysical regime of Egypt in relation to heat flow, ground water and microearthquakes, In: Said R: geology Egypt, 6: 61-89.

Ellis AL, Mahon WAJ (1977). Chemistry and geothermal systems. Academic Press. New York, p. 392.

Fairer G (1985). Geological map of Wadi Baish quadrangle, sheet 17F, Kingdom Saudi Arabia.

Fournier RO, Rowe JJ (1966). Estimation of underground temperatures from the silica content of water from hot springs and wet-steam wells. Am. J. Sci., 264: 685-697.

Fournier RO (1977). Estimating the subsurface formation temperature of the geothermal reservoirs using the soluble chalcedony. Geothermics, 5: 41-50.

Fournier RO, Potter A (1982). Using of quartz geo-thermometer as indicator for subsurface temperatures. GRC Bulletin, pp. 3-12.

Giggenbach WF (1986). Graphical techniques for the evaluation of water-rock interaction conditions by use of $\mathrm{Na}, \mathrm{K}, \mathrm{Mg}$ and $\mathrm{Ca}$ contents of discharge waters. In: Proc. $8^{\text {th }}$ New Zealand Geothermal Workshop, pp. 37-44.

Giggenbach WF (1988). Geothermal solute equilibria derivation of $\mathrm{Na}-$ $\mathrm{K}-\mathrm{Mg}-\mathrm{Ca}$ geoindicators. Geochim. Cosmochim. Acta, 52: 27492765.

Jeffrey S, John E (1990). Geographic Information Systems, an introduction. Prentice-Hall, Inc., p. 303.

Lashin A (2007). Evaluation of the geothermal potential around the coastal parts of the Gulf of Suez-Egypt, using well logging and the geo-thermometer data. Egypt J. Appl. Geophys., 6(2): 215-248.

Lashin A, Arifi N (2010). Some aspects of the geothermal potential of Egypt. Case study: Gulf of Suez-Egypt. Proceedings World Geothermal Congress, Bali-Indonesia, p. 6.

Lillesand TM, Kiefer RW (1994). Remote Sensing and Image Interpretation, Jon Wiley \& Sons, New York, p. 750.

Sonka M, Hlavac V, Boyle R (1993). Image processing, analysis and machine vision. Chapman\&Hall, London, p. 555.

Swanberg CA, Morgan P, Boulos FK (1983). Geothermal potential of Egypt. Tectonophysics, 96: 77-94. 